\title{
The European Union
}




\section{ECONOMICS TODAY}

Edited by Andrew Leake

The Economics Today series surveys contemporary headline topics in applied economics. Each book in the series is written by an expert in the field in a style that is fluently readable. It serves the student of introductory economic principles while also making the subject accessible to a more general reader. The series embraces the problem-solving skills of the new generation of students and stresses the importance of real-world issues and the significance of economic ideas.

\section{Published}

Andrew Leake: The Economic Question

Jean-Louis Barsoux and Peter Lawrence: The Challenge of British Management

Andy Beharrell: Unemployment and Job Creation

Frank Burchill: Labour Relations

Mark Cook and Nigel M. Healey: Growth and Structural Change

Kenneth Durham: The New City

S. F. Goodman: The European Union (3rd edition)

Ian Hodge: Environmental Economics

Kent Matthews: Macroeconomics and the Market

Charles Smith: Economic Development, Growth and Welfare

Jenny Wales: Investigating Social Issues

John Wigley and Carol Lipman: The Enterprise Economy

Margaret Wilkinson: Taxation

\section{Series Standing Order}

If you would like to receive future titles in this series as they are published, you can make use of our standing order facility. To place a standing order please contact your bookseller or, in case of difficulty, write to us at the address below with your name and address and the name of the series. Please state with which title you wish to begin your standing order. (If you live outside the United Kingdom we may not have the rights for your area, in which case we will forward your order to the publisher concerned.)

Standing Order Service, Macmillan Distribution Ltd, Houndmills, Basingstoke, Hampshire, RG21 6XS, England. 


\section{THE EUROPEAN UNION}

Third Edition

S. F. Goodman 
(C) S. F. Goodman 1990, 1993, 1996

All rights reserved. No reproduction, copy or transmission of this publication may be made without written permission.

No paragraph of this publication may be reproduced, copied or transmitted save with written permission or in accordance with the provisions of the Copyright, Designs and Patents Act 1988, or under the terms of any licence permitting limited copying issued by the Copyright Licensing Agency, 90 Tottenham Court Road, London W1P 9HE.

Any person who does any unauthorised act in relation to this publication may be liable to criminal prosecution and civil claims for damages.

First edition (The European Community) 1990

Reprinted 1991, 1992

Second edition 1993

Reprinted 1993

Third edition (The European Union) 1996

Published by

MACMILLAN PRESS LTD

Houndmills, Basingstoke, Hampshire RG21 6XS

and London

Companies and representatives

throughout the world

ISBN 978-0-333-66266-3 ISBN 978-1-349-14094-7 (eBook)

DOI 10.1007/978-1-349-14094-7

A catalogue record for this book is available from the British Library.

$\begin{array}{llllllllll}10 & 9 & 8 & 7 & 6 & 5 & 4 & 3 & 2 & 1\end{array}$

$\begin{array}{llllllllll}05 & 04 & 03 & 02 & 01 & 00 & 99 & 98 & 97 & 96\end{array}$ 
For Helen 


\section{Contents}

List of Tables and Figures xiv

Preface xvii

List of Abbreviations xxi

Acknowledgements xxiv

1 Contemporary Issues 1

Revision of the Treaty on Union 1

Economic Issues 3

Old Issues Persist 4

Deepening and Widening the Union 4

The Single European Act 6

The Pillars of the Treaty on Union 7

Decision-making in the European Union

The Commission 9

The Council 10

The European Parliament 11

The European Court of Justice 12

The European Court of Auditors 12

The Trialogue 13

European Union Legislation 13

Regulations 14

Directives 14

Decisions 14

Recommendations and opinions 14

Delegated legislation 15

How are Decisions Reached in the Council? 15 
What Sort of Union is Emerging?

A 'fortress Europe' 17

A free market for capitalists 21

A deregulated market 23

A multi-speed or variable-geometry Europe 24

Federalism and Subsidiarity 26

Conclusion 27

2 Ideas into Institutions - How the European

Union Began 29

The United Kingdom and Early Ideas for

European Unity 30

The New Ideas After $1945 \quad 31$

The New Organisations 32

The Organisation for European Economic Cooperation 32

The North Atlantic Treaty Organisation 34

The Brussels Pact and Western European Union 36

The Council of Europe 38

The Economic Organisations 39

The first economic institution - the European Coal and Steel

Community 41

Date Chart 43

3 Development and Change 46

The Six 46

What are the Economics of the European Union as a Customs Union? 47

Have the Hopes been Met? 49

Economies of Scale - the Great Sales Pitch? 52

Changing Political Attitudes in the United Kingdom 56

A Slow Change in the United Kingdom's Political

Orientation 56

EFTA 59

The United Kingdom's Successful Application $\quad 60$

The Entry Terms 62

Renegotiation and the Referendum 63

The Enlargement of the Community 66

The European Economic Area 68 
Flanking policies $\quad 70$

The cost of the agreement 71

Implications of the creation of the EEA 72

The institutions of the EEA 72

Europe Agreements 73

Partnership and Cooperation Agreements $\quad 77$

\section{Governing the Union 79}

How are Laws Made? 80

How are Legislative Measures Implemented? 83

Unanimous or Majority Decisions? 85

What is the Problem of National Sovereignty? 88

Will Sovereignty be an Issue in the Future? 93

Will the European Parliament be Adequate in the

Future? 94

Is the Union Bureaucratic? 96

A Budget Problem - Where to Get the Money 98

How are the Budget and Exchange Rate Fluctuations

Reconciled? 103

Another Budget Problem - the Winners and Losers

108

Fraud 111

Is the Community a Tower of Babel? 113

5 Agriculture - Successes, Failures, Reforms 115

Has the Common Agricultural Policy been

Successful? 115

Why would Free Market Competition in Agriculture

Cause Chaos? 116

Why have the Surpluses Occurred? 126

The EAGGF 131

Other Reasons for Oversupply 132

How have the Surpluses been Dealt With? 134

Reform Proposals 138

How Successful have the 1992 Reforms been? 142

Agrimonetary Compensation Mechanism 144

What of the Future? 146 
6 Economic Performance - Growth, Employment, Trade 148

Introduction 148

What Measures of Comparison are Useful? 149

How has the European Union Performed? 151

How do Working Hours Compare? 155

What have been the Longer-Term Trends? 157

Employment Comparisons 158

The White Paper on Growth, Competitiveness and Employment 161

The Service Sector 163

Trade Comparisons 164

How has intra-Community trade developed? 165

How has the European Union's external trade changed? 166

The changes in the European Union's current account balances 168

Visible trade 170

Invisible trade and current account balances

7 Money 174

What Determines the Value of the Various European

Currencies? 174

How Well does the Purchasing Power Parity Theory Apply? 175

Where does the Non-Speculative Demand and Supply of a Currency Come From? 175

What is the Role of Speculation in the Fixing of Exchange Rates? 177

Are there any Controls in the Foreign Exchange Markets? 178

Do Governments Allow their Exchange Rates to Float Freely? 180

Floating Exchange Rates, Monetarism and the Evolution of the EMS 182

What is the European Monetary System? 186

The European Monetary Cooperation Fund and EMI 186

The European Currency Unit 187

How the ECU 'basket' is made up 189 
The Exchange Rate Mechanism 190

What are the divergence indicators for? 195

What happens if a divergence indicator is reached? 195

What has been the Effect of the Exchange Rate

Mechanism since 1979? 196

Why did the United Kingdom Not Join the ERM until 1990? 197

The 'impossibility theorem' 199

Why was the United Kingdom forced out of the Exchange

Rate Mechanism? 199

Will the Single Market have much Impact on Money and Banking? 203

8 One Market, One Money? 207

The Delors Committee Report 207

Maastricht and Economic and Monetary Union 210

The 1995 Green Paper on Introducing a Single

Currency 216

The Green Paper's justification of a single currency 219

Other points in the Green Paper 219

The United Kingdom's Opt-out 220

The European System of Central Banks 221

Why have a Common Currency? 222

The Single Currency and Employment 224

The Theory of an Optimum Currency Area 225

The Future 226

Postscript: One market, One money 229

9 The Social and Economic Integration of Europe 233

Introduction 233

The Social Policy of the European Community 233

The European Structural Funds 234

The Cohesion Fund 238

What principles lie behind the distribution of Structural Funds? 240

What Areas does Social Policy Cover? 241 
How has the Social Policy Affected the Rights of Working Women? 244

The Social Charter 246

The impact of the Social Charter 247

Conclusion on the Social Charter 250

The Social Chapter of the Maastricht Agreement

10 Towards Sustainability - The Environment

The Community and the Environment 254

What is the population background? 255

How significant is energy use in the Union in the environmental context? 259

Has the European Union developed a coherent policy on the environment? 260

The European Environment Agency 261

How has the European Union Policy Developed? 263

The Treaty on Union and the environment 264

Eco-labels 265

Who should Pay to Protect the Environment? 265

Would energy taxes help? 267

11 Law and Democracy 271

Law and Justice 271

The origins of Community law 271

The Court of Justice 273

The role of the Court of Justice $\quad 275$

How do Community law and national law mix? 277

Democracy 279

The Democratic Deficit 282

A Conference of the Parliaments 283

The European Parliament 283

The committees of the Parliament 289

What impact have the MEPs made? 291

What are the budgetary powers of the European

Parliament? 295

The Commission, Guardian of the Treaties 296

The Council of Ministers 299 
The Ombudsman 301

Democracy and the Media 301

12 The Future and the Intergovernmental Conference 304

What Alternative Policies for Development are there? 305

A European Union Foreign and Security Policy? 306 The Treaty on Union and Foreign Policy 308

A European Union Defence Force? 309

A Transatlantic Economic Space 312

What will be the Effects of the Single Market on the

Location of Industry and Commerce? 313

What are the Gains from Membership? 316

Europe $2000 \quad 318$

Trans-European Networks 319

The Schengen Agreements $\mathbf{3 2 0}$

Is a New Police State being Developed? 324

Europol 324

The Intergovernmental Conference of 1996

325

The European Commission's submission 328

The European Parliament's submission 329

The Council of Ministers' submission 330

The Court of Justice's submission 330

Other submissions 330

What is the likely outcome of the IGC? 333

Concluding Thoughts 334

Bibliography 339

Index 341 


\section{List of Tables and Figures}

\section{Tables}

1.1 Classification of Legislation of the Treaty of Rome 13

3.1 The Referendum of June $1975 \quad 64$

3.2 The Basis for the United Kingdom's Grievance:

Contributions and Receipts from the Community

Budget 65

4.1 Qualified Majority Voting 86

4.2 The Dominance of Agricultural Payments: The Community Budget, $1985 \quad 101$

4.3 VAT Rates 102

4.4 United Kingdom Contributions to and Public Sector Receipts from the Community Budget 104

4.5 Expenditure on the Community Budget;

Commitments by Type of Expenditure, 1992-95 105

4.6 Members' Contributions to Community Budget Revenues, $1995 \quad 107$

4.7 Contribution to, and receipts from, the European Community Budget, $1993 \quad 107$

4.8 Financial Perspective for the Enlarged Community, 1995-99 108

4.9 Fraud 112

5.1 Commodity Intervention in the United Kingdom: An Example 128

5.2 Classified Agricultural Areas, $1991 \quad 133$

5.3 The Statistical Background to Agricultural Reforms 139

6.1 GDP at Market Prices per Head, 1989-93 152

6.2 Volume Indices of GDP 153 
6.3 Annual Rates of Growth of GDP 154

6.4 Total Public Expenditure on Research and Development 155

6.5 Changes in the Usual Working Week, 1983 to 1992156

6.6 Unemployment Rate 159

6.7 Total Imports and Exports by Partner Country, $1993 \quad 166$

6.8 The European Union's Main Trading Partners, $1993 \quad 167$

6.9 The European Union's Balance of Trade in Goods, 1985 and $1993 \quad 167$

6.10 Extra-Community Imports/Exports by Product Class, 1985 and $1993 \quad 168$

6.11 Balance of Trade with the Rest of the World 170

6.12 Balance of Visible Trade 171

7.1 Composition of the ECU and its Weights 190

7.2 The Currency Grid 192

7.3 An ERM Chronology 193

8.1 Are the Maastricht Convergence Criteria Being Met? 212

9.1 Resources Committed to the Cohesion Fund 239

9.2 Assistance from the Cohesion Fund in $1993 \quad 240$

10.1 Population Density in the European Union 256

11.1 Results of the June 1994 Elections for the European Parliament, Great Britain and Northern Ireland 285

11.2 European Elections: Electorate, Percentage Turnout, and Votes Cast 286

11.3 Political Groups in the European Parliament, 10 July $1995 \quad 288$

\section{Figures}

1.1 The Pillar Concept of the European Union 8

1.2 A Simplified Version of the European Union's Decision-making Procedure 10

3.1 The Institutional Structure of the EEA 74

3.2 Basic Statistics of the EEA 76

4.1 The Community's Decision-making Process 80

4.2 The Institutional Cooperation Procedure 81

4.3 The Codecision Procedure 84

4.4 Developments in Community Spending 110

5.1 'Cobweb' Effects 118 


\section{xvi List of Tables and Figures}

5.2 'Cobweb' Effects 120

5.3 Effects of Relative Inelasticity of Demand and Supply on Price 125

5.4 A Simplified Illustration of a 'Buffer Stock' System in Operation 127

5.5 Rent is Price-Determined 130

8.1 Introduction of a Single Currency - Sequence of Events 218

9.1 Regions Eligible for Aid under Objectives 1, 2 and 5b, 1994-99 237

9.2 Per Capita GDP in the Richest and Poorest Regions of Member States 242

9.3 The Application of the Qualified Majority Vote to Social Policy 249

10.1 Inland Consumption of Primary Energy 258

11.1 The European Court of Justice 274

11.2 The European Parliament, Composition July 1995290

12.1 Trans-European Networks - The First 14 Projects 321 Annex Issues on Which Unanimity is Required by the Council 335 


\section{Preface}

This third edition of The European Community is renamed The European Union and the change of title is more than symbolic. The Treaty on Union signed at Maastricht represents a watershed in the history of Western Europe because it shifts the emphasis of the European Community away from economic matters towards political affairs. Whilst there has been continued progress in economic, financial and social matters over the last three years, the stress has been on foreign and security policy and on justice and home affairs.

This edition contains detailed discussions of the most important economic, financial and social developments of recent years. The proposals for monetary union and a single currency are examined and the work of the new European Monetary Institute is explained. We now have the benefit of several new reports and decisions on monetary union. There is an analysis of the problems faced by the Exchange Rate Mechanism and of Britain's position in relation to it.

The book also includes analysis of the new regional policies, the Cohesion Fund and the Trans-European Networks that will transform the face of Europe over the next twenty years. Progress on social policies is also dealt with in the context of the Social Chapter reforms of the Treaty and the United Kingdom's opt-out. The environmental context of industrial change is of increasing importance and this section of the book has been expanded.

The future route taken by the European Union depends to a great extent on its success in tackling unemployment so this edition deals at length with the Delors White Paper on 'Growth, Competitiveness and Employment' and its implications.

There have been various reforms put in place since the last edition so the progress of the reforms of the Common Agricultural Policy 


\section{xviii Preface}

and of the 1992 Single Market are discussed in detail. The issue of fraud is also examined. The issues raised by the Schengen Agreements are of very great importance for the future of Europe and are dealt with in detail.

The Treaty on Union included attempts to increase the democratic element in the Union, particularly in the role of the European Parliament. Much heat is generated by the concept of national sovereignty and by the question of majority voting in Council. A discussion of these themes appears throughout the book partly in the context of the future enlargement of the European Union to include Central and Eastern European states. The significance of the various agreements with these states is surveyed. There is also an examination of the effects of the enlargement in 1995 to include Austria, Finland and Sweden and of the European Economic Area.

Developments in these areas, and in social policy, together with the enlargement of the Union will make the Europe of the twentyfirst century very different from that of the late 1950s when the European Economic Community was conceived.

There are topics that are not covered in the detail that some might wish. These include the extremely complex Common Fisheries Policy which is now largely about conservation, or should be, and has become very divisive. There is also little coverage of the Small and Medium Sized Enterprise initiatives being fostered so keenly by the Union. The main area of omission, however, is the scientific research field which has produced a large number of ever-changing initiatives.

The European Community has an exceptionally good statistical office (Eurostat). Its publications are available in all good reference libraries. Eurostat produces an excellent illustrated book called 'Europe in Figures', first published in 1988 and revised every two years. This is an ideal publication for the general reader who wants an easily assimilated and comprehensive coverage of the Community in statistical terms. It is superbly presented as is the more comprehensive $A$ Social Portrait of Europe which contains magnificent coloured maps, charts and statistics. Its superb 142 pages at ECU 10, or $£ 7.25$ via HMSO bookshops, throws into sharp relief the tax on knowledge imposed by our own United Kingdom authorities in pricing works such as the annual Social Trends at $£ 34$. Recent European Union statistics present some problems because 
of German reunification and because of the impact of the Single Market from 1 January 1993 on trade statistics. The new system run by Intrastat has suffered from the failure of businesses to make returns.

The European Union also has a first-class information service. The Information Office of the Commission of the European Communities at 8 Storey's Gate, London SW1P 3AT, provides a wide range of free material as well as subscription matter. Some is in the form of Background Reports and some are periodicals in the European Documentation series. These periodicals, of which there are a large number, cover specific topics in great detail. They are an excellent starting point from which to begin the study of a given subject. The European Parliament has its own information service at 2 Queen Anne's Gate, London SW1H 9AA. Their material too is up to date and well presented.

Since these largely free sources of up-to-date information about the Union are readily available, I have tried in this book to concentrate on ideas, trends and developments rather than upon creating a factual reference book. By far the best single-volume reference book about the European Communities is The European Community: A Practical Guide for Business, Media and Government by Morris, Boehm and Geller (Macmillan). It contains excellent flow charts of all the main institutions and policies and an explanatory dictionary of all the main terms and bodies connected with the Community. It also lists all the legislation applicable to different areas of Community activity. The reader who wants a much more detailed analysis of the economic theory underlying the Community should read Edward Nevin's The Economics of Europe (Macmillan, 1990).

Jean Monnet, the 'father of the Community', said 'we are not forming coalitions between states, but union among people'. In other words, European integration is aimed at the hearts and minds of ordinary people. He concluded his memoirs by saying 'and the Community itself is only a stage on the way to the organised world of tomorrow'.

This great vision of Monnet, who was an extremely practical man, can only be fully appreciated against a historical background. This is why this book has a section evaluating the historical context of the progress of the Community. The Anglo-Saxon experience of modern history has been markedly different from that of the 


\section{xx Preface}

continental European. In this difference lies the explanation of our alternative views of the Community, of the European Union, its institutions and its future.

S. F. GoOdMAN 


\section{List of Abbreviations}

ACP African, Caribbean and Pacific

AFTA

ASEAN Free Trade Area

AOSIS

Alliance of Small Island States

ASEAN

Association of South-East Asian Nations

B

Belgium

BENELUX Belgium, The Netherlands and Luxembourg

CAD Capital Adequacy Directive

CAP Common Agricultural Policy

CCT Common Customs Tariff

CEE Central and Eastern Europe

CEFTA Central European Free Trade Association

CFP Common Fisheries Policy

CFSP Common Foreign and Security Policy

CIS Commonwealth of Independent States (ex-USSR)

COREPER Committee of Permanent Representatives

CPI Consumer Price Inflation (see also RPI)

CSCE Conference on Security and Cooperation in Europe

D Germany

DGs Directorates-General

DK Denmark

E Spain

EAGGF European Agricultural Guidance and Guarantee

Fund

EC European Community

ECB European Central Bank

ECOFIN Council of Economic and Finance Ministers

ECSC European Coal and Steel Community

ECU European Currency Unit 


\section{xxii List of Abbreviations}

$\begin{array}{ll}\text { EEA } & \text { European Economic Area } \\ \text { EFTA } & \text { European Free Trade Association } \\ \text { EIB } & \text { European Investment bank } \\ \text { EIS } & \text { European Information System } \\ \text { EMCF } & \text { European Monetary Cooperation Fund (now run } \\ & \text { by EMI) } \\ \text { EMI } & \text { European Monetary Institute } \\ \text { EMS } & \text { European Monetary System } \\ \text { EMU } & \text { Economic and Monetary Union } \\ \text { EPC } & \text { European Political Cooperation } \\ \text { EPP } & \text { European People's Party } \\ \text { EPU } & \text { European Payments Union } \\ \text { ERDF } & \text { European Regional Development Fund } \\ \text { ESCB } & \text { European System of Central Banks } \\ \text { ESF } & \text { European Social Fund } \\ \text { EU } & \text { European Union } \\ \text { EUA } & \text { European Unit of Account } \\ \text { EURATOM } & \text { European Atomic Energy Community } \\ \text { EUROPOL } & \text { European Police } \\ \text { F } & \text { France } \\ \text { FIFG } & \text { Financial Instrument for Fisheries Guidance } \\ \text { FIN } & \text { Finland } \\ \text { FTA } & \text { Free Trade Area } \\ \text { GATS } & \text { General Agreement on Trade in Services } \\ \text { GATT } & \text { General Agreement on Tariffs and Trade } \\ \text { GDP } & \text { Gross Domestic Product } \\ \text { GNP } & \text { Gross National Product } \\ \text { GR } & \text { Greece } \\ \text { I } & \text { Italy } \\ \text { IBRD } & \text { International Bank for Reconstruction and } \\ \text { IGC } & \text { Development } \\ \text { ILO } & \text { Intergovernmental Conference } \\ \text { IMF } & \text { International Labour Organisation } \\ \text { IMP } & \text { International Monetary Fund } \\ \text { INF } & \text { Integrated Mediterranean Programmes } \\ \text { IPC } & \text { Integrated Pollution Control } \\ \text { IRENE } & \text { Irregularities, Enquiries, Exploitation } \\ \text { IRL } & \text { Ireland } \\ \text { JCC } & \text { Joint Consultative Council } \\ & \end{array}$


JHA

L

LFA

MCA

MEP

MFN

MGQ

NAFTA

NATO

NL

OCA

OECD

OEEC

OSCE

P

PCA

PPP

PPS

QMV

RPI

RPIX

S

SEA

SDR

START

STV

TARGET

TENS

UA

UAA

UK

VAT

VSTF

WEU

WTO
Justice and Home Affairs

Luxembourg

Less Favoured Areas

Monetary Compensatory Amount

Member of the European Parliament

Most Favoured Nation

Maximum Guaranteed Quantity

North American Free Trade Association

North Atlantic Treaty Organisation

Netherlands

Optimum Currency Area

Organisation for Economic Cooperation and

Development

Organisation for European Economic Cooperation

Organisation for Security and Cooperation in

Europe

Portugal

Partnership and Cooperation Agreement

Purchasing Power Parity

Purchasing Power Standards

Qualified Majority Vote

Retail Price Index (also CPI)

Retail Price Index excluding mortgage interest

payments

Sweden

Single European Act

Special Drawing Rights

Strategic Arms Limitation Talks (Treaty)

Single Transferable Vote

Trans-European Automated Real-Time Gross

Settlements Express Transfer System

Trans-European Networks

Unit of Account

Utilised Agricultural Area

United Kingdom

Value Added Tax

Very Short Term Facility

Western European Union

World Trade Organisation 


\section{Acknowledgements}

The author and publishers wish to thank the following for permission to reproduce copyright material:

The Controller of Her Majesty's Stationery Office for extracts from European Community Finances, Cm 2824, Tables 4.4, 4.5, 4.6, 4.8 and Figure 4.4, and, from Agriculture in the United Kingdom 1994, Table 5.1. Crown Copyright is reproduced with the permission of the Controller of HMSO.

The Central Statistical Office for permission to reproduce Table 4.7 from Social Trends 1995.

The European Monetary Institute for permission to reproduce Table 8.1.

The Office for Official Publications of the European Communities for their generous help and for permission to reproduce tables, data and figures from their publications, particularly from Basic Statistics of the European Union, 1994 and 1995, from Frontier Free Europe and from the European Documentation and Europe on the Move series.

The author would like to thank the Information Services Unit of the European Commission for its help and unfailing courtesy and the Information Office of the European Parliament for providing so much valuable material. The Public Enquiries Group of the Bank of England were extremely helpful in answering queries and providing information. The German Embassy and the European Free Trade Association also gave considerable help. I would like to 
thank my wife, Lindsay, for her help with the index and bibliography and for her encouragement.

S.F.G. 